\title{
THE SOCIO-ECONOMIC BENEFITS OF MICROFINANCE: CONVENTIONAL VS. ISLAMIC
}

\author{
Amela Trokic ${ }^{1}$, Eldina Barakovac ${ }^{2}$ and Velid Efendic ${ }^{3}$ \\ ${ }^{1}$ European Association for Islamic Economics Banking and Finance, Bosnia and Herzegovina, amelatrokic@gmail.com. \\ ${ }^{2}$ University of Sarajevo, Bosnia and Herzegovina velid.efendic@efsa.unsa.ba. \\ ${ }^{3}$ Islamic Relief, Bosnia and Herzegovina, eldina@islamic-relief.ba.
}

\begin{abstract}
The reduction of poverty and socio-economic development has become a foremost issue in modern society. One approach to improving this was the establishment of microfinance, which has since become an important part of poverty alleviation strategies, but very few studies have considered its benefits based on characteristics other than poverty. Therefore, this study aims to investigate and determine how different client characteristics affect the way people benefit from the financing provided by microfinance institutions. Data were gathered from the beneficiaries of both conventional and Islamic microfinance using a questionnaire, and then analysed using the Kruskal-Wallis and the Mann-Whitney U tests. The results show how MFI financing benefits clients differently based on certain characteristics, as well as how these socioeconomic benefits differ based on whether the financing is provided by a conventional or an Islamic MFI. Overall, conventional and Islamic MFIs have similar strategies when it comes to providing socio-economic benefits to their clients. However, where they diverge is when client gender is considered, as IMFIs are more likely to benefit women. This research will be beneficial to MFIs in terms of the development of their services, as it will help them identify the strengths and weaknesses of their offerings and how well these are able to assist them in fulfilling their purpose of providing benefit to the poorest of the poor, increasing financial inclusion and contributing to socio-economic development.
\end{abstract}

Keywords: Islamic vs. conventional microfinance, Islamic microfinance, Socio-economic development, Poverty alleviation, Financial inclusion.

JEL Classification: B55; I3; G21; O10; Z130.

Article history:

Received : July 29, 2019

Revised : November 30, 2019

Accepted : January 8, 2020

Available online : February 28, 2020

https://doi.org/10.21098/jimf.v6i1.1162 


\section{INTRODUCTION}

\subsection{Background}

The reduction of poverty and socio-economic development has become a foremost issue in modern society. People without or with a very small income face many difficulties in everyday life. These families struggle daily; they have difficulties in acquiring basic foodstuff, they do not have enough money to finance the education of their children, and they lack access to healthcare and medicaments. Financial exclusion further traps them in a vicious circle of poverty (Abdelkader \& Salem, 2013) because they do not have access to financing which could help improve their lives. Therefore, it can be concluded that poverty is one of the biggest moral challenges of our time (Malim, 2011). This problem can, however, be solved if we determine a comprehensive and holistic approach towards increasing financial inclusion. One such approach to improving the living conditions of poor people, while increasing financial inclusion, was the establishment of microfinance. When Muhammad Yunus established the Grameen Bank in 1976, which provided banking for the poor, he presented to the world a truly effective approach to poverty alleviation (Vatta, 2010). He was the pioneer and founder of the modern microfinance industry, which allows non-bankable people and people without collateral to take out a loan and finally become part of the formal financial system. The Consultative Group to Assist the Poor (CGAP) defined microfinance as "the provision of financial services to low-income people" (CGAP, 2014). Over time, microfinance has been identified and accepted as an important part of poverty alleviation strategies, and subsequently the global microfinance industry has experienced significant growth worldwide.

At the same time, there is a need among Muslim populations for the establishment of MFIs that offer products that are in accordance with the Shari'ah, also known as Islamic law, since many countries with significant populations living under the poverty line are identified as being majority Muslim. Therefore, Islamic microfinance has also experienced rapid growth due to the high demand, particularly from poor countries such as Indonesia, Bangladesh and Afghanistan, where such demand for Islamic microfinance products is particularly high, and which account for around 80 percent of global outreach (Abdelkader \& Salem, 2013). Islamic MFIs are an alternative to conventional MFIs, providing poor people with basic financial services at low cost.

However, low-income people are not all the same and even their needs differ according to different characteristics besides low-income. Some have issues arising from their marital status, in which they not only lack income, but also support from an extended family. Others may be victims of sexism and the gender stereotypes perpetuated by their respective societies. Often, these characteristics may create additional barriers which affect beneficiaries' income and the way in which microfinancing assists them. Therefore, there is a need to consider how microfinance institutions benefit people socio-economically based on differing characteristics; that is to say, to determine whether different client characteristics affect the way they benefit from such institutions.

A great number of studies have already conducted in the field of microfinance and poverty alleviation. However, those focusing on microfinance in Bosnia and Herzegovina $(\mathrm{B} \& \mathrm{H})$ are only related to conventional microfinance. There are a 
very limited number of studies on B\&H concerning the socio-economic impact of Islamic microfinance. This study highlights microfinance and examines its importance for socio-economic development in B\&H. It also examines the interest in Islamic microfinance in a secular society with a significant Muslim population and measures its impact on its beneficiaries in comparison with their conventional counterparts. Furthermore, the study is very important in light of current global issues. Many refugees and other migrants escaping conflict in their countries have found their way to Europe in search of a better life and increased economic opportunities. As is well known, the majority of these refugees and migrants are Muslim and are coming from predominantly Muslim societies, which, to varying degrees, operate according to Islamic norms. These individuals will be in need of aid, and in order to keep them from becoming stuck in the poverty cycle, while also freeing them from social benefits which render them dependent on the state, financing will be required. B\&H, as a secular European country with a dominant Muslim population, serves as a perfect example for other European countries with significant Muslim populations, such as Germany and France. This research, which examines the concepts of financing poorer populations using Shari'ah-compliant models in a secular financial system, serves as an excellent case study, and its results could be applicable to other European countries, such as those mentioned above. Therefore, the study has significant applications outside the scope of the particular case and will provide useful insight into the possibilities of Islamic microfinance on a global scale.

\subsection{Objectives}

The objectives of this research are as follows:

- To explain how MFIs operate and the foundations of their work;

- To investigate the impact of MFIs on socio-economic development by determining their significance in improving the standard of living (in terms of education, health, savings, business and employment opportunities, and similar aspects) of their beneficiaries;

- To compare the socio-economic impact of Islamic MFIs vs. conventional MFIs on the standard of living of their beneficiaries;

- To explain Islamic microfinance as an alternative (and possibly more effective) approach to socio-economic development and improvement in living standards.

\section{LITERATURE REVIEW}

\subsection{Background Theory}

Reducing poverty has become an important global goal. According to the United Nations (UN), 836 million people still live in extreme poverty (United Nations, 2014). Many organisations, governments and individuals have developed projects aimed at attempting to assist those who live in very poor conditions, with microfinance being one strategy.

Many studies have provided insight into the positive effects of microfinance, especially on the lives of those who receive micro-financing, i.e. the beneficiaries. 
In 1999, the World Bank investigated 675 beneficiaries of micro-financing in Bangladesh, with the aim to determine how it affected their lives. The results of the study indicated that there was a positive correlation between the receipt of microfinance assistance and a better standard of living, both from economic and social perspectives. This indicates that there is an interdependence between socioeconomic factors and microfinance assistance. However, the most interesting result of this study was that the positive impact was largely triggered by the increased participation of women through self-employment as a result of micro-financing (Lavoori \& Paramanik, 2014).

Since 1999, many studies have been conducted around the world confirming these results by finding positive correlations between microfinance and increased employment, female empowerment and the better economic and social status of the beneficiaries. Gangaiah et al . (2006) conducted a study in India which investigated the relationship between microfinance and economic status. They found that microfinance impacted income generation in an Indian village positively, where the beneficiaries were able to increase their household income by using microfinance loans to create self-employment opportunities. Paul (2014) found similar results, particularly where job creation and self-employment were concerned. He found that creating opportunities for self-employment was a very important role of microfinance, but also that through different microfinance programmes, beneficiaries were encouraged to improve other aspects of their lives, such as health, children's education and nutrition.

Kumar et al . (2008) conducted a study in Northern India but found that the first round of financing from an MFI was not enough to create favourable impacts or to change the lives of the beneficiaries. Instead, it was not until the second round of financing that an increase in employment or skills development could be seen. Nevertheless, by empowering the poor we are building a society where even those of lower economic status can contribute to social and economic development, thus breaking the chain of dependency and increasing self-confidence (Vachyah \& Kamaiah, 2015). Santosh et al. (2016) confirmed this, showing how microfinance significantly contributed to the wellbeing of beneficiaries in India.

Mathur and Mathur (2016) claimed that microfinance played two roles in socio-economic development; first by supporting the poorer members of society, and second by promoting self-employment and encouraging people to become more productive, thus contributing to job creation, and benefitting the community at large.

More recent studies have begun to focus on female empowerment in order to determine how effective microfinance actually is in helping women gain independence, particularly in male-dominated societies. As a holistic approach, microfinance has had a great impact, especially on female empowerment, where it has successfully helped them fulfil their needs without being dependent on others (Santosh et al., 2016). According to Aseanty and Hassan (2013), MFIs are increasingly targeting women for three reasons: the rate of repayment among women is higher than with men; women have fewer employment opportunities in developing countries; and women distribute their money better when making multiple investments, such as investing in the improvement of their households, in their children, and in micro-businesses. However, Fiona (2014) found that it was 
not enough to provide women with micro-financing, but that they also needed to be educated through informative materials and skills training. This is because her study found that while microfinance loans were able to provide self-employment, once these activities became commercialised, men took over.

\subsection{Previous Studies}

Islamic microfinance and Islamic MFIs have gained interest over recent years, especially in low-income Muslim communities, where conventional MFIs have low penetration rates as the public refuses to use non-Shari'ah-compliant products. Consequently, numerous studies have analysed Islamic microfinance in the hope of providing strategies which provide the socio-economic development benefits of microfinance, but in a manner which is permissible from an Islamic perspective.

Many studies on the benefits of Islamic microfinance have shown similar results to those conducted on conventional microfinance. Rahman (2010) conducted an empirical study of Bangladesh, considering access to Islamic microfinance. He found that the beneficiaries of Islamic microfinance were able to significantly increase their household income and employment upon receiving financing. Rahman also suggested that Islamic microfinance may be more efficient in poverty alleviation because it is more likely to encourage ethical behaviour. This ethical approach in turn leads to more desirable economic behaviour, thus promoting economic growth. Ahamad et al. (2016) also found that Islamic microfinance significantly contributed to the economic development of beneficiaries and their households.

Some authors have suggested a preference for Islamic microfinance, especially in Muslim countries and communities where it is more welcome, but also in conventional societies, which could also benefit from the added ethical principles (Haneef et al., 2014). Obaidullah and Khan (2008) indicated that Islamic microfinance was effective as a development tool due to its ability to reach the poorest of the poor, which even conventional while Islamic microfinance does not follow their example. Islamic MFIs also have more rigorous monitoring requirements, which tend to contribute to the success of their financing, since they also provide support alongside funding (Zouari \& Nabi, 2013). This is because providing financial services is not the only task for Islamic MFIs. They also must ensure that beneficiaries receive adequate education, consultation and cooperation. This process in an Islamic context is called the shuratic process, or that of consultation (Abdul Gafar Ismail , 2014). Providing finance through Islamic MFIs is therefore much more than simply interest-free financing. It involves a whole system which intends to enhance and improve the overall condition of society in accordance with Shari'ah objectives (Dusuki, 2008).

Islamic microfinance is, however, not without its faults. Abdelkader and Salem (2013) conducted a study comparing Islamic and conventional MFIs in terms of technical efficiency in the Middle East and North Africa. The authors found that there were no significant differences in efficiency between the two and concluded that using products which are in accordance with Shari'ah does not affect the performance of MFIs. Nevertheless, Sugema et al. (2010) suggested that the profitloss sharing contracts which constitute the foundations of Islamic economics, and 
therefore Islamic microfinance, could be further improved to allow for increased distribution of funds and the effective reduction of income inequality.

Regarding Islamic microfinance in B\&H, only one Islamic MFI is currently operating in the country (Efendic \& Hadzic, 2017). According to Khan (2008), Islamic Relief established microfinance in $\mathrm{B} \& \mathrm{H}$ and through their program offered microcredits based on Qard Hasan and Murabaha. Their primary goal was to provide aid to widowed women and orphaned children from the Bosnian War. In fact, Islamic Relief was initially established as a charity in B\&H before restructuring as an MFI. Subsequently, most of their efforts have continued to be focused on providing aid to disadvantaged families and on female empowerment.

Overall, most of the literature has found very few differences between conventional and Islamic microfinance. While many studies point to the significant contribution microfinance makes to economic development, few identify any differences in its approach and effect. Some have even shown that Shari'ah compliance makes no difference to the performance of the microfinance institution. However, none of these studies considers specific demographic characteristics, but instead generalise the poor populations as a whole, considering only how microfinance affects overall poverty, rather than how it affects individuals with varying characteristics living in poverty. Similarly, no studies on this specific topic have been conducted in $\mathrm{B} \& \mathrm{H}$, which is an interesting case, not only as a European Muslim country, but as one which serves as an example of the successful implementation of microfinance (mainly in the post-Bosnian war years).

\section{METHODOLOGY}

\subsection{Data}

The research made use of both theoretical and empirical data, with both sets needing to be collected appropriately. Theoretical data refer to the data collected for the purpose of developing the study's theoretical background and literature review. These data comprise the collection of secondary data from numerous articles and texts from other authors. The literature used included journal articles, proceedings, books, reports, and published and unpublished empirical studies . Both online and printed sources were considered. The fields of interest included Islamic finance, microfinance, Islamic microfinance and takaful, poverty alleviation strategies, socio-economic development and other academic fields which were the focus of the study.

The empirical data were collected using a questionnaire. This included a set of questions which were administered to the target group in the same, pre-arranged order (Saunders et al., 2012). Questionnaires are most efficient when they are simple and straightforward, so that respondents clearly understand what is being asked of them, thus reducing the chances of uncertainty and limiting the amount of inaccurate information (Onwuegbuzie \& Hitchcock, 2017). The questionnaire used was clearly divided into four sections with very straightforward questions, and was tested through a pilot study.

The first section consisted of 10 questions related to the respondent's demographic characteristics and financial situation. All the questions in this section were multiple choice, with respondents required to choose one answer from a set 
of possible answers provided for each question. The second section contained only one question, which asked the respondents to indicate why they had opted for an Islamic MFI. This was also a multiple choice question; however, respondents were able to choose more than one option if necessary. The third section included questions concerned with the respondents' perceptions of the Islamic MFI of which they were a beneficiary, namely its impact on various aspects of their lives. They were asked to rate the extent to which they agreed with the statements provided, thereby providing their related perceptions. This section used a Likert scale which ranged from 1, strongly disagree, to 5, strongly agree. The statements focused on various aspects of the respondents' social and economic status before and after receiving financing from the Islamic MFI. The fourth and final section of the questionnaire was structured in exactly the same way as the third section. However, this section was concerned with the respondents' perceptions of the conventional MFI of which they were also a beneficiary.

The target population were individuals who were clients of both the Islamic and a conventional MFI in B\&H. Subsequently, a sample of 263 respondents was included in the target group, representing the total number of clients using both conventional and Islamic microfinance in all of $\mathrm{B} \& \mathrm{H}$. Once this target population had been identified, each individual was contacted by telephone due to feasibility constraints resulting from their widespread geographical situation across the country. Out of the total population of 263 potentially relevant respondents, 84 valid responses were collected, meaning the usable response rate was around 32 percent. As there are not many individuals who are beneficiaries of both the Islamic and a conventional MFI in $\mathrm{B} \& \mathrm{H}$, it was difficult to obtain a larger sample. Many clients were hesitant to provide information, as they were distrustful and could not be convinced of the anonymity of the research. Nevertheless, while this may seem to be a small sample, it must be emphasised that it represents 32 percent of the entire target population and not just 32 percent of a given sample. As such, we believe it is sufficient to represent the entire population.

Descriptive statistics were used to develop a respondent profile in terms of demographic characteristics and financial status, as well as a summary of the overall perception of the beneficiaries of the impact of both Islamic and conventional microfinance on the quality and standard of their lives. Inferential statistical analysis included the use of Kruskal-Wallis and Mann-Whitney U tests to examine the research question. The tests were conducted on demographic factors by the socio-economic benefits of MFIs. Both of these are nonparametric methods and an appropriate analysis method to evaluate differences between distribution and the socio-economic benefits of MFIs. The assumptions were that the samples drawn from the population were random, that the observations were independent of one another, and that the measurement scale of the socio-economic benefits, which represent the dependent variables, were at least ordinal, which is validated since they are measured on a Likert scale.

While the overall target population of the research are individuals who are beneficiaries of both Islamic and conventional MFIs, this research not only seeks to determine how they have benefitted from each differently, but it also aims to determine how each of the MFIs benefit them based on specific characteristics. In other words, not only is it necessary to determine whether people benefit more 
from Islamic compared to conventional MFIs, but how these benefits manifest themselves based on their demographic characteristics such as age, gender, and marital status, as we are dealing with different populations, such as men and women, different age groups and so on. Therefore, the Kruskal-Wallis test is ideal for such an analysis between different groups/populations.

\subsection{Model Development}

Primarily, and to fulfil the first objective of the study, the research established a strong theoretical foundation by reviewing the relevant literature. As previously mentioned, many academic sources were used for this purpose. As such, we were able to establish the operations of MFIs and the foundations of their work. This was important in the development of our model, since it contributed to the creation of the questionnaire used to collect the empirical data.

Due to the fact that our data do not follow normal distribution, the following tests were deemed most appropriate. The Kruskal-Wallis test was conducted for the following demographic groups, because they comprised more than two subgroups:

- Age: 21-40 years old, 41-60 years old, and 60 years or older.

- Level of education: primary school, secondary school and university.

- Number of members in household: Fewer than 2, and 2-5.

- The Mann-Whitney test was conducted for the following demographic groups which only had two sub-groups:

- Gender: male or female.

- Religion: Islam and other.

- Marital status: married or unmarried.

- Role as decision maker in household: yes or no.

- Income level: less than or equal to 500 BAM or more than 500 BAM.

- Savings held: yes or no.

- Size of loan received from MFI: less than or equal to 5000 BAM or more than 5000 BAM.

Running either the Kruskal-Wallis or Mann-Whitney test, we obtained $p$-values which represent the statistical differences between the mean scores of the perceptions of MFIs of the different demographic groups. Statistical significance is represented by $p$-values which are lower than 5 percent $(p<0.05)$.

The tests were conducted to answer the question: How do the socio-economic benefits of microfinance institutions differ based on client characteristics, and how do these differences vary based on whether the MFI is Islamic or conventional?

The hypotheses were formulated as follows:

$\mathbf{H}_{\mathbf{0}}=\quad$ There is no difference in the socio-economic benefits of MFIs among different categories of MFI clients.

$\mathbf{H}_{\mathbf{a}}=\quad$ There are different socio-economic benefits of MFIs among different categories of MFI clients. 


\subsection{Method}

Following the ontology and epistemology of the research, we used an objectivist philosophy which aims to determine whether the socio-economic benefits of MFIs vary among different categories of clients, or beneficiaries, of MFI services (Trokic, 2016). Understanding research philosophy is important for defining research strategy or practical methodology (Saunders et al., 2009). The study also seeks to investigate the impact of microfinance benefits on various aspects of the lives of the beneficiaries without prejudice from the researchers, who otherwise remain uninvolved in the research itself, without having any personal interest in the issue. In that respect, the study is also positivist. Positivism relies on facts and reality, examining social phenomena and their causes when the collected data are measurable and can be statistically analysed. Positivism also entails a deductive research approach through which hypotheses are empirically tested (Vercic et al., 2010). Unlike positivism, social constructionism relies heavily on the observations of the researchers, who may also be part of the situation, and therefore provides generalisation though theoretical abstraction rather than statistical probability (Ramanathan, 2008).

\section{RESULTS AND ANALYSIS}

\subsection{Results}

The demographic profiles of the respondents affect the results and therefore it is important to understand the demographic make-up of those who participated in the research data collection. Particularly when considering perception, demographic factors such as gender and age can greatly affect one's viewpoint and thus affect the manner in which questions are answered. Understanding the profile of respondents helps us place the empirical results into context and can later lead to stronger analysis (Table 1). The respondent profile was established by using descriptive statistics to analyse the findings, namely frequency and percentages.

Table 1.

Demographic Profile of the Respondents

\begin{tabular}{llccc}
\hline \multirow{2}{*}{ Gender } & & Frequency & \% & Total \\
\hline \multirow{3}{*}{ Age Group } & Male & 38 & 45.2 & \multirow{2}{*}{84} \\
& Female & 46 & 54.8 & \\
\hline \multirow{2}{*}{ Religion } & 21-40 years of age & 24 & 28.6 & \\
& 41-60 years of age & 41 & 48.8 & \multirow{2}{*}{84} \\
& 61 or older & 19 & 22.6 & \\
\hline \multirow{3}{*}{ Marital Status } & Islam & 83 & 98.9 & \multirow{2}{*}{84} \\
& Other & 1 & 1.2 & \multirow{2}{*}{84} \\
& Single & 6 & 7.1 & \\
& Married & 52 & 61.9 & \multirow{2}{*}{8.3} \\
\hline
\end{tabular}


Table 1.

Demographic Profile of the Respondents (Continued)

\begin{tabular}{|c|c|c|c|c|}
\hline & & Frequency & $\%$ & Total \\
\hline \multirow{4}{*}{ Educational Level } & Primary School & 7 & 8.3 & \multirow{4}{*}{84} \\
\hline & Secondary School & 52 & 61.9 & \\
\hline & Bachelor & 24 & 28.6 & \\
\hline & Postgraduate (Master or PhD) & 1 & 1.2 & \\
\hline \multirow{3}{*}{$\begin{array}{l}\text { Number of Members } \\
\text { in the Household }\end{array}$} & $\begin{array}{l}\text { Fewer than } 2 \text { members in the } \\
\text { household }\end{array}$ & 10 & 11.9 & \multirow{3}{*}{84} \\
\hline & 2 to 5 members in the household & 71 & 84.5 & \\
\hline & $\begin{array}{l}\text { More than } 5 \text { members in the } \\
\text { household }\end{array}$ & 3 & 3.6 & \\
\hline \multirow{2}{*}{$\begin{array}{l}\text { Are you the Head/Main } \\
\text { Decision Maker of your } \\
\text { Household? }\end{array}$} & Yes & 75 & 89.3 & \multirow[b]{2}{*}{84} \\
\hline & No & 9 & 10.7 & \\
\hline
\end{tabular}

Source: Author, 2019

According to the analysis of the demographic attributes of the respondents, nearly all of the beneficiaries which participated in the questionnaire, apart from one, claimed to follow the Islamic faith. This is unsurprising, considering that the MFI in question is an Islamic one, which openly targets individuals who seek Shari'ah-compliant microfinancing products and services (Smolo, 2013). The majority of respondents (61.9 percent) claimed to have a secondary school education, while the second largest group claimed to have an undergraduate university degree, representing 28.6 percent of the sample. This means that the majority of the sample had at least a secondary school education, while more than a quarter were educated to university level.

The average size of the respondents' families was between 2 to 5 members. Most of the respondents, 61.9 percent, were married, while surprising 22.6 percent were widowed. If we consider size of household and marital status together, we can assume that the results probably suggest that most respondents had children. In addition, the majority of respondents were aged between 21 and 40 years and were living in a society and culture which places significance on family and childbearing.

89.3 percent of the respondents claimed to be the main decision makers in their household. If we consider that nearly 55 percent were female, this is surprising, since many studies point to the fact that while women tend to receive microfinancing more than men, they are not the main decision makers within the household. This is why much of the literature points to the fact that financing may be given to women, but often tends to be controlled by men (Fiona , 2014; Santosh et al., 2016). Nevertheless, the respondents may be referring to their current status after having received financing from the MFI, which will be determined by further analysis later in this chapter. 
Table 2.

Financial Status of the Respondents

\begin{tabular}{lccc}
\hline \multicolumn{1}{c}{ Financial Status } & Frequency & $\%$ & Total \\
\hline Monthly income & 1 & 1.2 & \\
None & 5 & 6.0 & 84 \\
Less than 300 BAM & 45 & 53.6 & \\
301 - 500 BAM & 33 & 39.3 & \\
More than 500 BAM & & & \\
\hline Savings & 1 & 1.2 & 84 \\
Yes & 83 & 98.8 & \\
No & & & \\
Value of financing obtained from the Islamic MFI & 80 & 95.2 & 84 \\
Less than 5,000 BAM & 4 & 4.8 & \\
5,000 - 10,000 BAM & 0 & 0 & \\
More than 10,000 BAM & & & \\
\hline
\end{tabular}

Source: Author, 2019

Considering the financial status of the respondents (Table 2), all apart from one claimed to have no savings. This is not surprising, since individuals seeking microfinancing tend not to have a reserve of funds (Maitrot \& Hulme, 2014). Moreover, considering that the majority of respondents claimed to have a monthly income of between 301 and $500 \mathrm{BAM}$, in a country where the average consumer basket for a family of 4 is nearly 1,800 BAM (klix.ba , 2016), it is highly unlikely that savings are an option. Furthermore, it is likely that many of the respondents were receiving social benefits, which are usually between 300 and 500 BAM.

The fact that nearly all of the respondents received only 5,000 BAM in financing from the MFI may seem odd at first. However, it should be noted that the Islamic MFI only began providing financing of more than 5,000 BAM nearly 2 years ago (Berryman \& Pytkowska, 2014). Since Islamic MFIs have to follow the Shari'ah, they cannot receive funding from commercial banks. In a secular economy, this makes it very difficult to secure Shari'ah-compliant sources of funding (Abdelkader and Salem, 2013). This is the case with the Islamic MFI in B\&H, which initially did not have sufficient funding and, in an attempt to reach as many beneficiaries as possible, offered lower amounts.

\subsection{Analysis}

Considering the important role demographic attributes play in clients' perceptions of MFIs, both Islamic and conventional, it is important to determine how different categories of clients benefit from different types of MFIs, and whether some benefits are more, or less, beneficial to them. As mentioned, the Kruskal-Wallis and the Mann-Whitney U tests were used to evaluate the differences in distribution between demographic groups.

If we observe all the p-values of the two tests, we can establish which client characteristics are statistically significant in terms of the benefits from MFI offerings. From the results, it can be seen that the client characteristics with the most statistically significant results are age, education level, number of household 
members, and income. However, this is not the same for all the socio-economic benefits, meaning that clients do not benefit from MFI offerings in the same way. It will first be considered in more detail how clients benefit based on varying characteristics from the two types of MFI.

\subsubsection{How MFIs Benefit Clients based on Age}

The results in Table 3 indicate that clients aged between 21 and 40 benefit more from certain MFI services than older clients.

In terms of education and employment opportunities, younger clients are more likely to benefit than older ones. The former are more in need of education than the latter, as the assumption is that older clients have either already received or had the chance to receive an education, which could provide them with more employment opportunities. If older clients did not have education opportunities, it would stand to reason that their investment potential would be much lower than it would be with younger clients, who have a higher chance of living longer and hence the benefits of additional education, which would only be seen after a certain period of time, would be higher. The education they receive could help gain employment, which younger clients are more likely to secure as they are more employable than older ones. In general, the 21 to 40 age group is the optimal working category, so it stands to reason that it would be easier to employ individuals who fall into this group. Increased education and employment opportunities often go hand in hand with increased income, which is also why younger clients are more likely to enjoy this benefit from MFIs, as indicated by the results. Alternatively, older clients are more likely to receive increased healthcare than younger ones. Since older clients are more prone to health issues, MFIs would need to provide them with more healthcare benefits than younger clients.

Table 3.

Clients' Age and MFI Benefits

\begin{tabular}{|c|c|c|}
\hline \multirow[t]{2}{*}{ Benefit } & \multicolumn{2}{|c|}{$\begin{array}{c}\text { Age } \\
(21-40 \text { vs. } 41-60 \text { vs. } 60+) \\
\end{array}$} \\
\hline & IMFI & CMFI \\
\hline Better access to education & 0.001 & 0.001 \\
\hline Better access to healthcare & 0.001 & 0.001 \\
\hline More employment opportunities & 0.001 & 0.001 \\
\hline Overall material situation improved & 0.036 & 0.169 \\
\hline Living standards of beneficiary and family improved & 0.002 & 0.040 \\
\hline Increased savings & 0.053 & 0.161 \\
\hline Increased income & 0.001 & 0.001 \\
\hline Role in decision making improved & 0.003 & 0.419 \\
\hline
\end{tabular}

Source: Author, 2019

However, it must be stated that despite the variations in the benefit received based on age, there is no significant difference in the socio-economic benefits delivered by Islamic and conventional MFIs. This means that, regardless of which 
institution clients receive assistance from, the benefits they receive are similar, in line with their given characteristics. In other words, Islamic and conventional MFIs do not appear to have differing strategies in how they aid their clients. Instead, both prioritise their offerings based on client age in similar ways. For example, both prioritise increased health services for older clients, while prioritising education and employment opportunities for younger ones.

\subsubsection{How MFIs Benefit Clients based on Gender}

While the results pertaining to how clients receive benefits from MFIs based on gender (Table 4) were not statistically significant, meaning we cannot reject the null hypothesis that there are no differences, there were some interesting observations.

Table 4.

Clients' Gender and MFI Benefits

\begin{tabular}{lcc}
\hline \multirow{2}{*}{ Benefit } & \multicolumn{2}{c}{$\begin{array}{c}\text { Gender } \\
\text { (Female vs. Male) }\end{array}$} \\
\cline { 2 - 3 } & IMFI & CMFI \\
\hline Better access to education & 0.239 & 0.359 \\
Better access to healthcare & 0.871 & 0.427 \\
More employment opportunities & 0.591 & 0.841 \\
Overall material situation improved & 0.726 & 0.337 \\
Living standards of beneficiary and family improved & 0.744 & 0.817 \\
Increased savings & 0.727 & 0.191 \\
Increased income & 0.172 & 0.815 \\
Role in decision making improved & 0.522 & 0.702 \\
\hline
\end{tabular}

Source: Author, 2019

Women were far more likely to benefit from increased educational opportunities provided by MFIs as a socio-economic benefit than men, whether the service was provided by an Islamic or conventional MFI. This may be correlated to the social norms present in poorer areas, which are often the target of MFI services, where women are not provided with the same educational opportunities as men are, and thus require more support in securing an education. In this respect, it is clear why women are more likely to receive educational benefits from MFIs.

Similar results can be seen with increased income, where MFIs benefit women more than men. This may be linked to the fact that MFIs provide more educational opportunities, which give women additional skills that allow them to earn more. It could also be a result of the multiple projects funded by MFIs that help women earn money from the handicrafts they make; this does not constitute employment, but does lead to a higher personal income. It should also be noted that this benefit is more evident in IMFIs than conventional ones, which signifies that IMFIs may focus more on female clients than male ones.

This is further seen when we consider that almost all the other socio-economic benefits provided by conventional MFIs favour men, while in IMFIs women are more likely to enjoy these benefits. This means that conventional MFIs provide 
more socio-economic benefits to male clients, thus clearly showing gender discrimination. On the other hand, Islamic MFIs favour female clients slightly more than male ones except where access to education and increased income are concerned, then an evident gender bias favours woman . Evidently, Islamic and conventional MFIs have different strategies with regard to choosing clients based on gender, with discrimination on the basis of this client characteristic being far greater among conventional MFIs.

In the study by Obaidullah and Khan (2008) similar results can be seen, albeit not necessarily in the same way. They found that Islamic MFIs were more effective than conventional ones in their ability to reach the poorest of the poor. In many cases, these are women who have not had as many educational opportunities as their male counterparts and who are often constrained by cultural gender roles, which trap them in the cycle of poverty. In this respect therefore, our research found similar results to those of Obaidullah and Khan (2008), since we also found that Islamic MFIs were more effective and had a greater impact on helping women.

\subsubsection{How MFIs Benefit Clients based on Level of Education}

The results in Table 6 indicate that individuals with less formal education, up to primary school level, benefit less from MFIs, regardless of whether they are conventional or Islamic. This is true for all socio-economic benefits except healthcare, in which case, the less educated a client, the more likely they are to benefit from such access. This may be due to the fact that those with higher education may be more aware of healthcare options than those with less education. In this respect, simple medical options that are obvious to more educated clients may not be available to less educated ones, due to their lack of knowledge of the issues. Therefore, MFIs may be able to benefit less educated individuals with better access to healthcare simply by educating them on basic health and medicine topics. Similarly, those with less formal education could be from areas which lack education institutions, accounting for the lack of related opportunities. If this is the case, then they are also likely to live in places without healthcare facilities, so any form of additional healthcare options is considered a drastic change and benefit.

It is interesting to note that even when it comes to better access to education, the least educated clients benefit less than those with higher levels of education. However, this does not account for changes in the level of education as a result of MFI support, as no data was obtained on education level before and after receiving assistance. This means that clients who indicated primary school education could have received this either before or after becoming clients, which would indicate two very different trends. Therefore, we cannot draw conclusions on this point, but encourage future research to examine the issue more thoroughly. 
Table 5.

Clients' Level of Education and MFI Benefits

\begin{tabular}{lcc}
\hline & \multicolumn{2}{c}{ Level of Education } \\
\cline { 2 - 3 } Benefit & IMFI & CMFI \\
\cline { 2 - 3 } & 0.009 & 0.008 \\
\hline Better access to education & 0.018 & 0.060 \\
Better access to healthcare & 0.032 & 0.037 \\
More employment opportunities & 0.048 & 0.180 \\
Overall material situation improved & 0.003 & 0.093 \\
Living standard of beneficiary and family improved & 0.100 & 0.124 \\
Increased savings & 0.021 & 0.169 \\
Increased income & 0.099 & 0.169 \\
Role in decision making improved & & \\
\hline
\end{tabular}

Source: Author, 2019

Despite the evident variations in benefits based on level of education, there is no significant difference in the socio-economic benefits delivered by Islamic and conventional MFIs. Both types of institution provide similar benefits, meaning that both have much more work to do when it comes to benefitting less educated clients.

\subsubsection{How MFIs Benefit Clients based on Marital Status}

Clients who are unmarried appear to receive more benefit from MFIs than married ones (Table 6). This is true for all aspects, apart from better access to healthcare, which married clients benefit from more.

Table 6.

Clients' Marital Status and MFI Benefits

\begin{tabular}{lcc}
\hline & \multicolumn{2}{c}{ Marital Status } \\
\cline { 2 - 3 } Benefit & \multicolumn{2}{c}{ (Married vs. Unmarried) } \\
\cline { 2 - 3 } & IMFI & CMFI \\
\hline Better access to education & 0.656 & 0.311 \\
Better access to healthcare & 0.898 & 0.652 \\
More employment opportunities & 0.621 & 0.241 \\
Overall material situation improved & 0.783 & 0.572 \\
Living standard of beneficiary and family improved & 0.227 & 0.307 \\
Increased savings & 0.17 & 0.431 \\
Increased income & 0.834 & 0.455 \\
Role in decision making improved & 0.186 & 0.211 \\
\hline
\end{tabular}

Source: Author, 2019

This could be explained by the fact that most single clients are females from rural areas, who generally require more support and can thus enjoy greater benefits from MFIs. To test this, we further analysed the data collected. Of the 
32 individuals who were unmarried, 28 were women. In fact, out of those who stated they were widowed, 89 percent were women, while 100 percent of those who stated that they were divorced were women.

In addition, married people are also more likely to have a bigger support group, which would include their spouse and spouse's family, so that any MFI support received is just another link in the chain, especially when the unmarried person is a woman who has lost the support of a man, in a society which is traditionally patriarchal. The support of an MFI would make up for such a loss and mean considerably more to an unmarried woman than it would to an unmarried man. Regardless of this, the results do not indicate any significant difference in conventional versus Islamic MFI benefits.

\subsubsection{How MFIs Benefit Clients based on Size of Household}

Smaller households generally benefit less from MFI support than larger ones in all aspects of the socio-economic benefits measured by this study (Table 7).

Table 7.

Size of Clients' Household and MFI Benefits

\begin{tabular}{lcc}
\hline \multirow{2}{*}{ Benefit } & \multicolumn{2}{c}{ Size of Household } \\
\cline { 2 - 3 } & \multicolumn{2}{c}{$(<2$ vs. 2-5 vs. $>\mathbf{5})$} \\
\hline Better access to education & IMFI & CMFI \\
Better access to healthcare & 0.006 & 0.013 \\
More employment opportunities & 0.477 & 0.447 \\
Overall material situation improved & 0.033 & 0.007 \\
Living standard of beneficiary and family improved & 0.058 & 0.038 \\
Increased savings & 0.033 & 0.028 \\
Increased income & 0.609 & 0.270 \\
Role in decision making improved & 0.019 & 0.004 \\
\hline
\end{tabular}

Source: Author, 2019

In terms of education opportunities, larger households usually mean they include children who are likely to receive educational support, and so it would follow that larger families benefit more from better access to education. Similarly, larger families are more likely to have very young or very old members who require increased healthcare, thus also benefitting more from better access . Larger households are also more likely to have members of a working age who could benefit more from better employment opportunities, in turn leading to increased income. These benefits to clients with larger families are similar, regardless of whether the MFI is conventional or Islamic.

\subsubsection{How MFIs Benefit Clients based on other Characteristics}

MFI clients with a higher income are more likely to benefit from MFIs in nearly all socio-economic aspects, whether they are conventional or Islamic. This shows a 
gap in MFI efforts to reach the poorest of the poor through increased educational and employment opportunities. Unfortunately, this does very little to end the poverty cycle which many financially impoverished clients find themselves in. Instead, it is likely that any financial support offered by MFIs goes towards consumption, rather than helping beneficiaries increase their standard of living and other socio-economic aspects of their lives.

Religion, as a client characteristic, did not produce a statistically significant result, which is probably due to the fact that nearly100 percent of the sample indicated that they followed Islam. Therefore, the sample was not diverse enough to produce interesting results. The same situation occurs with regard to the size of loan received; our initial division into two groups of less than or equal to 5000 BAM and more than 5000 BAM resulted in almost all of the respondents choosing the former.

\section{CONCLUSION AND RECOMMENDATION}

\subsection{Conclusion}

As established by previous studies and further confirmed through this research, the role of MFIs is to provide aid to their beneficiaries to help them increase their standard of living. In this way, they contribute to the socio-economic development of the poorer populations, most often the poorest of the poor. This often involves providing aid through education, healthcare benefits, and employment opportunities, amongst others. This research was able to identify and present conclusions related to the operation and foundations of the work of MFIs, both Islamic and conventional, thus fulfilling its first objective. Based on the results, it was also possible to achieve the other objectives by investigating exactly how MFIs fulfil their purpose and impact socio-economic development, while also comparing the approach of Islamic and conventional MFIs. It was also established how Islamic microfinance serves not only as an alternative to conventional offerings, but in some cases is much more effective.

It is concluded that overall, conventional and Islamic MFIs have similar strategies when it comes to providing socio-economic benefits to their clients. Where age is concerned, both prioritise healthcare for elderly clients, while education opportunities, employment prospects and support for increasing income are more likely to benefit younger clients. Both conventional and Islamic MFIs do a good job of prioritising the needs of their clients and offering services and benefits accordingly, thus making the most of their financing programs and maximising their efforts.

Clients with a higher education are more likely to benefit from MFIs in all respects apart from better access to healthcare. In this aspect, clients with less formal education are more likely to benefit, which is probably a direct result of their lack of education. However, MFIs, whether conventional or Islamic, should recognise that less educated clients may need more support to make the most of their financing. Additional support services, such as financial advice, aimed at helping less educated clients better distribute the financing they receive from an MFI, may assist in increasing the benefits. 
Both conventional and Islamic MFIs prioritise unmarried individuals, offering greater benefit to them than married clients. Considering that women are more likely to fall into this category, usually as widows or divorcees, MFIs are successful in providing more support to clients who lack or have lost a support system such as a spouse or extended family, especially since beneficiaries often come from patriarchal settings, where the role of and need for men are heightened. The need of women lacking this form of support is therefore reinforced.

Both types of MFI are similarly concerned with providing aid to those who need it the most, such as families with more dependents, who could either be children or the elderly. Consequently, clients with larger households benefit more from MFIs than those with smaller ones. Where income is concerned, MFIs fail to break the "cycle of poverty" as they do not benefit the poorest members of society more than clients with larger incomes.

However, where conventional and Islamic MFIs diverge in their socioeconomic benefit to clients is when we consider gender. While both benefit women more than men in terms of providing better access to education, when it comes to almost every other socio-economic aspect there are significant differences. Conventional MFIs evidently discriminate on the basis of gender, often benefitting male clients more than female ones. IMFIs are less likely to have this gender bias, but are slightly more likely to favour women, especially when efforts to assist in increasing income are concerned. Therefore, there is a clear difference in the socio-economic benefits of conventional and Islamic MFIs on the basis of clients' gender. Men would benefit more from becoming clients of conventional MFIs, while women should seek out IMFIs to receive greater benefits. Considering that women tend to be more socially excluded than men, IMFIs are making the effort to include them more than conventional MFIs are, and in that respect they are more concerned with fulfilling their social goals as opposed to simply the economic ones. Conventional MFIs should look to their Islamic counterparts for inspiration when it comes to gender inclusion.

\subsection{Recommendations}

The impact of this research is of significance to both theory and practice. It contributes to the literature by building on previous research and filling the gap identified. Namely, it provides insight into the role of MFIs in developing economies which are characterised by large Muslim populations but are culturally, legally and socially secular. It also provides a dual perspective, since it is concerned with beneficiaries of both Islamic and conventional microfinancing. Its application to practice is also of note, as it provides MFIs with feedback on the impact of microfinancing on their beneficiaries, which areas they should focus on in terms of their service offering, and how they can improve their operations. This is important to Islamic MFIs in particular, who can improve their approach to conventional financial markets in order to increase the number of beneficiaries they are able to reach. This research is therefore transferable to all Islamic MFIs operating in conventional economies.

Overall, it is evident that despite its limitations the research was able to obtain strong results that are beneficial to the field of microfinance. The results build 
on previous studies and provide a foundation for further research, which could further examine the impact of Islamic and conventional microfinancing on the standard of living of its beneficiaries. Therefore, the research has both theoretical and practical implications, allowing it to be of use to both academia and Islamic and conventional MFIs.

\section{REFERENCES}

Abdelkader, I.B., \& Salem, A.B. (2013). Islamic vs Conventional Microfinance Institutions: Performance analysis in MENA countries. International Journal of Business and Social Research, 3(5), 219-233.

Abdul Ghafar Ismail , R., A. (2014). Al-Tawhid in Relation to the Economic Order of Microfinance Institutions. Humanomics, 30(4), 325-348.

Ahamad, S., Bakar, R., \& Lubis, Z. (2016). Islamic Microfinance and Its Impacts on Borrowers: A Systematic Review from 1995-2015. Mediterranean Journal of Social Sciences MCSER Publishing , 7(6), 113-120.

Aseanty, D., \& Hassan, A. (2013). Islamic Microfinance, Socio-economic Wellbeing of Women and Their Families in Bangladesh. Paper presented at The Sharia Economics Conference, Hannover .

Berryman, M., \& Pytkowska, J. (2014). A Review of the Bosnian Microfinance Sector: Move to Self-Sufficiency. Microfinance Centre .

Biety, M.M., \& Rutledge, S. (2012). Bosnia and Herzegovina: Diagnostic Review of Consumer Protection in the Microfinance Sector. Washington D.C.: The World Bank.

Bryman, A., \& Bell, E. (2011). Business Research Methods. (3rd ed.) Oxford: Oxford University Press.

CGAP (2014). What is Microfinance? How Does It Relate to Financial Inclusion? Retrieved January 17, 2017, from http://www.cgap.org/about/faq/whatmicrofinance-how-does-it-relate-financial-inclusion-0

Chapra, M. U. (2001). What is Islamic Economics? Jeddah, Saudi Arabia: Islamic Development Bank, Islamic Research and Training Institute.

Dar, H. (2013) Women Empowerment through Islamic Banking and Finance. Retrieved January 30, 2017, from http://www.freemalaysiatoday.com/category/ opinion/2013/07/15/women-empowerment-through-islamic-banking-andfinance/

Dusuki, A. W. (2008). Banking for the Poor: The Role of Islamic Banking in Microfinance Initiatives. Humanomics, 24(1), 49-66.

Efendic, V. (2014). Business Model and Operational Efficiency of Microfinance in Bosnia and Herzegovina [Lecture]. Islamic Microfinance. 2014. Sarajevo: UNSAEFSA.

Fiona , J. (2014). Role of Microfinance in the Socio-Economic Development of Women. Socrates, 2(3), 123-136.

Gangaiah, C., Nagaraja, B., \& Vasudevulu, N.C. (2006). Impact of Self-Help Groups on Income and Employment: A Case Study. Kurukshetra .

Haneef, M.A., Muhammad, A.D., Pramanik, A.H., \& Mohammed, M.O. (2014). Integrated Waqf Based Islamic Microfinance Model (IWIMM) for Poverty 
alleviation in OIC Member Countries. Middle-East Journal of Scientific Research, 19(2), 286-298.

Hulme, D., \& Maitrot, M. (2014). How Do We Save The Soul of Microfinance?. Retrieved January 28, 2017, from https://theconversation.com/how-do-wesave-the-soul-of-microfinance-32345

Khaled, M. (2011). Why Has Islamic Microfinance Not Reached Scale Yet? Retrieved January 30, 2017, from http://www.cgap.org/blog/why-has-islamicmicrofinance-not-reached-scale-yet

Khan, A. A. (2008). Islamic Microfinance: Theory, Policy and Practice. Birmingham: Islamic Relief Worldwide

Khan, M.A. (2013). What is Wrong with Islamic Economics: Analysing the Present State and Future Agenda. UK : Edward Edgar Publishing Limited.

Kumar, V., Sharma, R.K., \& Sharma, H.R. (2008). Impact of Micro Financing on Income and Employment: Micro Evidence from Himachal Pradesh. Financing Agriculture: A National Journal of Agriculture and Rural Development, 40(1), 3-8.

Lavoori, V., \& Paramanik, R.N. (2014). Microfinance Iimpact on Women's Decision Making: A Case Study of Andhra Pradesh. Journal of Global Entrepreneurship Research, 4(11), 1-13.

Ledesma, G. (2015). Measuring and Monitoring Client Outcomes: Holding Ourselves Accountable for Social Performance. Microfinance Barometer 2015, 6, 4.

Malim, M., (2011). Islamic Microfinance: Solution to Poverty Alleviation? Islamic Finance News, 8(46), 2 -26.

Mathur, N. \& Mathur, H. (2016). Assessment of Microfinance as an Effective Tool for Socio Economic Development. Imperial Journal of Interdisciplinary Research (IJIR), 2(4), 1020-1026.

Mersland, R., D'espallier, B., \& Supphellen, M. (2013). The Effect of Religion on Development Effort: Evidence from the Microfinance Industry and a Research Agenda. World Development, 41, 145-156.

Mujkovic, A. (2010). Microcrediting in Bosnia and Herzegovina: What went wrong?. Retrieved January 28, 2017, from https://www.microfinancegateway. org/library/microcrediting-bosnia-and-herzegovina-what-went-wrong

Munir, K. (2014). How microfinance disappointed the developing world. Retrieved January 28, 2017, from https://theconversation.com/how-microfinancedisappointed-the-developing-world-23206

Ninkovic-Papic, R. (2012) Report of Social Entrepreneurship in BEH. Sarajevo: Foundation for Social Inclusion.

Nugroho, L. (2015). Islamic Principles versus Green Microfinance. European Journal of Islamic Finance (EJIF), 2(3), 1-9.

Obaidullah, M. (2008). Introduction to Islamic Microfinance. New Delhi: IBF Net.

Paul, U. (2014). Microfinance is anti-poverty tool for rural development; A study. International Journal of Development Research, 4(4), 915-918.

Pobric, R. (2015) LjudipermanetnonapuštajuBiH: Dvamiliona - brojkojiraste! [People are permanently leaving B\&H: Two million - a growing number!]. Retrieved February 20, 2017, from <http://www.6yka.com/novost/89612/ljudipermanetno-napustaju-bih-dva-miliona-broj-koji-raste

Rahman, M.M. (2010). Islamic Microfinance Program and Its Impact on Rural Poverty Alleviation. International Journal of Banking and Finance, 7(1), 119-138. 
Sachs, J. (2005), The End of Poverty - Economic Possibilities of Our Time. New York, USA: The Penguin Press.

Santosh, K., Subrahmanyam, S. E. V., \& Narayana, T., (2016). Microfinance - A Holistic Approach towards Financial Inclusion. Imperial Journal of Interdisciplinary Research (IJIR), 2(9).

Sirageldin, I. (2000). Elimination of poverty: Challenges and Islamic strategies. Islamic Economic Studies,8(1), 1-16.

Sugema, I., Bakhtiar, T., and Effendi, J. (2010). Interest versus Profit-Loss Sharing Credit Contract: Efficiency and Welfare Implications. International Research Journal of Finance and Economics, 45, 1450- 2887.

Trokic, A. (2016). Is Religiosity Important in Islamic Banking? Exploring Customer Choice and Awareness of Islamic Banking: Case Study of BBI Bank in Bosnia and Herzegovina. MA. University of Sarajevo and University of Bolton.

Trokic, A., \& Efendic, V. (2016). Alternative Banking - Does Religiosity Play an Important Role in Islamic Banking? Paper presented at The 7th International Conference on Islamic Banking and Finance Risk Management Regulation and Supervision (ICIBF2016), Sarajevo .

United Nations. (2014) The UN Millennium Development Goals. Retrieved January 17, 2017, from <http://www.un.org/sustainabledevelopment/poverty/

Vachyah, L., \& Kamaiah, B., (2015). Microfinance Impact on Socio-Economic Empowerment: A Special Reference to Andhra Pradesh. International Journal of Finance E Banking Studies, 4(1), 51-70.

Welle-Strand, A., Kjøllesdal, K., \& Sitter, N., (2010). Assessing Microfinance: The Bosnia and Herzegovina Case. Managing Global Transitions, 8(2), 145-166.

Zouari, Z., \& Nabi, M.S. (2013). Enhancing The Enforceability of Islamic Microfinance Contract in OIC countries. Jeddah: Islamic Research and Training Institute (IRTI). 
This page is intentionally left blank 